\title{
Spontaneous bacterial peritonitis: risk factors and relationship to serum-ascites albumin gradient in chronic liver disease patient
}

\author{
R.K ${ }^{1}$, Bhushan $\mathbf{M}^{2}$, Nigam $\mathbf{P}^{3}$ \\ ${ }^{1}$ Dr Rakesh Kumar, Professor of Medicine, B.R.D Medical College, Gorakhpur, UP, India, ${ }^{2}$ Dr Mridul Bhushan, \\ Associate Professor of Medicine, Government Medical College, Kannouj, ${ }^{3}$ Dr P. Nigam, Ret Professor and Head, \\ Department of Medicine, B.R.D Medical College, Gorakhpur, UP, India.
}

Address for Correspondence: Dr Rakesh Kumar, Drrkshahigkp@ gmail.com

\begin{abstract}
Background: Spontaneous bacterial peritonitis (SBP) is probably the best characterized infectious complication that develops in patients with cirrhosis and ascites. Aims and objective: The present study was done to find the incidence of SBP in patients of chronic liver disease and to find its correlation with serum ascites albumin gradient. Material and Methods: A total of 55 patients were selected for the study and divided into 2 groups; Group A- spontaneous bacterial peritonitis (SBP) and Group B -sterile cirrhotic ascites (SCA). Diagnosis was done by calculating SAAG (Serum Ascites Albumin Gradient) which reflects the differences in osmotic pressure and correlates with portal venous pressure. Total ascitic protein and ascitic- serum total protein ratio were taken as a diagnostic parameter for SBP. Results: Maximum incidence of disease was found between 31-50 years of age. Serum albumin values in SBP $(2.50 \pm 0.31 \mathrm{gm} / \mathrm{dl})$ when compared with SCA $(2.85 \pm 0.39)$ and total ascites albumin in SBP $(0.41 \pm 0.21)$ with SCA $(0.89 \pm 0.31)$ were significantly different $(\mathrm{p}<0.001, \mathrm{t}=3.59$ and $\mathrm{p}<0.001, \mathrm{t}=6.58$ respectively). No significant difference $(\mathrm{p}>0.05, \mathrm{t}=1.17)$ was found in serum ascites albumin gradient (SAAG), when it was compared between SBP $(2.09 \pm 0.42 \mathrm{mg} / \mathrm{dl})$ and SCA $(1.96 \pm 0.37$ $\mathrm{gm} / \mathrm{dl}$ ). Conclusion: In a patient of cirrhosis with ascites early diagnosis of development of SBP in a case of SCA can prevent mortality.
\end{abstract}

Keywords: Spontaneous Bacterial Peritonitis, SAAG, Serum cirrhotic ascites.

\section{Introduction}

Chronic liver disease is one of the foremost causes of morbidity and mortality throughout the world, posing a major socioeconomic challenge. About half the patients with cirrhosis develop ascites. Ascites has been defined as accumulation of excess fluid within the peritoneal cavity. It is caused by cirrhosis in $75 \%$ cases, malignancy in $10 \%$ cases. In India one of its major causes is tuberculosis. If serum ascites albumin gradient is greater than $1.1 \mathrm{gm} / \mathrm{L}$, the patient has portal hypertension and if the gradient is less than $1.1 \mathrm{gm} / \mathrm{L}$, there is no portal hypertension [1].

Patients with severe chronic liver disease and ascites are predisposed to SBP. SBP can be defined as infected ascites fluid in the absence of a recognizable secondary

Manuscript received $27^{\text {th }}$ January 2016

Reviewed: $10^{\text {th }}$ February 2016

Author Corrected: $20^{\text {th }}$ February 2016

Accepted for Publication $3^{\text {rd }}$ March 2016 cause of ascites. The ascetic polymorph count exceeds 250 cells $/ \mathrm{mm}^{3}$ and culture is positive [1]. SBP occurs most commonly in conjunction with cirrhosis of liver. However, the disease has also been reported in adults with metastatic malignant disease, post necrotic cirrhosis, chronic active hepatitis, acute viral hepatitis, congestive heart failure, systemic lupus Erythematosus, it has also been reported in adults with no underlying disease.

The ascites total protein, albumin, globulin and complement concentrations in cirrhosis patients with SBP were significantly lower in patients with sterile ascites, demonstrating the importance of those factors in ascetic fluid defense against secondary bacterial infection [2]. Pathogenesis of SBP is related to defects in both the serum and ascetic fluid humoral immune system and systemic bacteremia [3]. 
With these interesting and controversial reports in the world literature and non availability of Indian literature, the present study has been undertaken to find the prevalence of SBP in cases of chronic liver disease and correlation of the SBP with serum ascites albumin gradient.

\section{Materials and Methods}

A case control study was done on 55 patients presented with sign and symptoms suggestive of SBP admitted in Department of Medicine of BRD Medical College and Nehru Chikitsalya Gorakhpur.

A written Informed consent from all patients and Institutional Ethics Committee approval was obtained before starting the study.

All diagnosed cases of chronic liver disease (CLD) with ascites were included in the study whereas patients who developed ascites due to other causes like malignancy, tuberculosis peritonitis, pancreatic ascites, congestive heart failure and acute viral hepatitis were excluded from the study.

Two groups were formed having 30 patients in Group A (patients with SBP) and 25 patients in Group B (with sterile cirrhotic ascites). Ascites was diagnosed clinically by demonstrating shifting dullness on percussion of abdomen, with or without as fluid thrill and same was confirmed by an ascetic tap.

Diagnosis of liver cirrhosis was on the basis of history of jaundice or chronic alcoholism, shrunken liver, splenomegaly and distended veins on the abdomen and confirmed using laboratory test, if ascetic fluid examination of proteins was less than $2.5 \mathrm{gm} / \mathrm{dl}$, WBC less than 250/ cu mm and a shrunken liver with coarse echo texture with portal hypertension using ultrasonography was observed.

Diagnosis of SBP was done if patients with liver cirrhosis presented with fever more than $100^{\circ} \mathrm{F}$, abdominal pain, rapidly increasing ascites, peripheral oedema, abdominal tenderness, rebound tenderness, increasing hepatic encephalopathy and confirmed as, if patients was found with ascetic fluid polymorph more than $250 / \mathrm{cu} \mathrm{mm}$.

Detailed history, physical examination and through abdominal examination was performed for all the patients.

Serum ascites albumin gradient (SAAG) was calculated using formula (SAAG=Serum albumin-Ascitic Albumin). Estimation of total protein in serum and ascetic fluid was done by Biuret method as per Henry et al and estimation of albumin in serum and ascetic fluid was done by dye binding methods using bromocresol green as per Doumas et al $[4,5]$.

Patients with clinical suspicion of SBP were given cefotaxime (inj. $1 \mathrm{mg}$ TDS) along with symptomatic treatment. Antibiotic was changed according to sensitivity reports. Patients in sterile cirrhotic ascites group were given ciprofloxacin $750 \mathrm{mg}$ once a week for prophylaxis against SBP.

All the data was analysed using IBM SPSS ver. 20 and expressed as mean \pm standard deviation (SD). Analysis was done using unpaired t-test and $\mathrm{p}$ value was calculated. $\mathrm{P}<0.05$ was considered to be significant.

\section{Results}

Mean age of the study patients in Group A and Group B was $41.72 \pm 12.06$ years and $42.3 \pm 11.81$ years respectively. The present study had showed that incidence of SBP in our city population was $54.55 \%$ from which maximum incidence was found in age group of 31-50 years.

In present study there were $19(76 \%)$ male and 6 (24\%) female in Group B with male to female ratio of $3.16: 1$ and 22 $(73.33 \%)$ males and $8(26.67 \%)$ females in Group A with male to female ratio of 2.75:1.

The presenting symptoms in Group A and Group B in present study were increasing ascites $(88 \%$ and $46.67 \%)$, peripheral edema $(76 \%$ and $63.33 \%)$, abdominal tenderness $(68 \%$ and $26.67 \%)$, temperature more than $100^{\circ} \mathrm{F}(64 \%$ and $26.67 \%)$; hepatic encephalopathy (52\% and $16.67 \%)$, rebound tenderness $(48 \%)$, chills (16\% and $6.67 \%)$ and decreased bowel sound $(8 \%)$.

There was a significant difference between all these symptoms between both the groups $(\mathrm{p}<0.05)$. 
Table-1: Showing correlation of different parameters in both the groups.

\begin{tabular}{|c|c|c|c|c|}
\hline Parameter & Group A & Group B & t value & P Value \\
\hline Total serum protein $(\mathrm{gm} / \mathrm{dl})$ & $5.57 \pm 0.73$ & $5.80 \pm 1.05$ & 0.95 & $>0.05$ \\
\hline Total ascetic protein $(\mathrm{gm} / \mathrm{dl})$ & $0.93 \pm 0.16$ & $1.57 \pm 0.59$ & 5.2 & $<0.001$ \\
\hline Ascetic/serum total protein ratio & $0.17 \pm 0.04$ & $0.27 \pm 0.09$ & 4.85 & $<0.001$ \\
\hline Total serum albumin $(\mathrm{gm} / \mathrm{dl})$ & $2.50 \pm 0.31$ & $2.85 \pm 0.39$ & 3.59 & $<0.001$ \\
\hline Total ascetic albumin $(\mathrm{gm} / \mathrm{dl})$ & $0.41 \pm 0.21$ & $0.89 \pm 0.31$ & 6.58 & $<0.001$ \\
\hline SAAG & $2.09 \pm 0.42$ & $1.96 \pm 0.37$ & 1.17 & $>0.05$ \\
\hline Total leukocyte count $\left(\mathrm{cells} / \mathrm{mm}^{3)}\right.$ & $10508 \pm 3571.29$ & $8333.33 \pm 2421.22$ & 2.68 & $<0.05$ \\
\hline Serum bilirubin $(\mathrm{mg} / \mathrm{dl})$ & $4.8 \pm 4.28$ & $3.38 \pm 4.3$ & 1.23 & $>0.05$ \\
\hline Serum creatinine $(\mathrm{mg} / \mathrm{dl})$ & $1.35 \pm 0.74$ & $1.25 \pm 0.38$ & 0.68 & $>0.05$ \\
\hline
\end{tabular}

Group A; spontaneous bacterial peritonitis (SBP), Group B; sterile cirrhotic ascites (SCA). Data is expressed as mean \pm SD. Serum-Ascites albumin gradient; SAAG

Total cells in ascetic fluid and total number of polymorphs in SBP group was $2560 \pm 2269.7$ cell/ $/ \mathrm{mm}^{3}$ and $2110.5 \pm 2007.6$ cells $/ \mathrm{mm}^{3}$ respectively. PMN count was $>500$ cells $/ \mathrm{mm}^{3}$ in all patients with SBP. All patients in SBP group were considered in Culture Negative Neutrocytic Variants.

Out of 25 Patients in Group A, $16(64 \%)$ were alive and 9 (36\%) patients died whereas in Group B out of 30 patients, 25 $(83.33 \%)$ patients were alive and $5(16.67 \%)$ patients died.

\section{Discussion}

Out of 55 patients of chronic liver disease, $45.45 \%$ cases were found to have culture negative neurocytic ascites (CNNA), which is a variant of SBP. Present study in this regard is in concordance with Hoefs et al, which concluded an incidence of $40 \%$ of SBP in cirrhotic patients [1].

In present study, the mean age of patients was $41.72 \pm$ 12.06 years in Group A and $42.3 \pm 11.81$ years in group B. Maximum incidence of SBP was found between 3150 yrs of age.

In sterile cirrhotic patients the mean total albumin was $2.85 \pm 0.39 \mathrm{gm} / \mathrm{dl}$, the mean ascetic fluid albumin was $0.89 \pm 0.31 \pm 0.06$ and serum ascites albumin gradient was $1.96 \pm 0.37$. Findings of this study are in accordance with Albillos et al who found the mean total serum albumin $2.9 \pm 0.9 \mathrm{gm} / \mathrm{dl}$ but differ from them in ascetic fluid albumin $(0.65 \pm 0.35 \mathrm{gm} / \mathrm{dl})$ and SAAG 2.05 \pm 0.45 [6]. Present study also differs from Pare and Hoefs et al in SAAG (1.85 \pm 0.45$)$.

The difference may be because of variation in the geographical prevalence or because of different etiology of cirrhosis in the two study groups [1,7]. The serum ascites albumin gradient found in present study was $>1.1$ in all the 30 cases of SCA which is similar to study of Pare and Hoefs et al which showed SAAG > 1.1 in $96.55 \%$ cases [1,7]. In SBP the mean total serum albumin was $2.504 \pm 0.31 \pm 0.06 \mathrm{gm} / \mathrm{dl}$, the mean ascetic fluid albumin was $0.41 \pm 0.21 \pm 0.04 \mathrm{gm} / \mathrm{dl}$ and mean serum ascites albumin gradient was $2.09 \pm 0.42 \pm 0.08$. Albillos et al also found total serum albumin as significant parameter in differentiation between two groups. This study corresponds to his study in this respect but found ascetic fluid albumin to be significant between the two groups [6]. S AAG was found as an insignificant parameter to diagnose or predict the SBP in cirrhotic patients with ascites.

Runyon and Hoefs et al found 50\% mortality in CNNA patients and $70 \%$ mortality in SBP patients. Present study favors their study in terms of high mortality in CNNA patients but it was lower (36\%) as compared to their study [8]. This may be due to early diagnosis and better treatment provided to patients with good therapeutic efficacy of antibiotics (cefotaxime) and general care hence preventing complications.

No comment can be made on mortality of SBP since all cases were culture negative. However, considering such higher mortality in spite of treatment, we strongly feel that enough caution and prompt investigation should be done in all cases of SCA. 


\section{Conclusion}

In a patient of cirrhosis with ascites, clinical appearance of raised temperature above $100^{\circ} \mathrm{F}$ with chills, increasing ascites, abdominal and rebound tenderness, hepatic encephalopathy and decreased bowel sound can be taken as early diagnostic parameters for the development of SBP in a case of SCA.

Total ascitic protein and ascitic/serum total protein ratio can be taken as a diagnostic parameter for SBP. These are more appropriately considered as risk factors (low ascetic protein and low ascetic/serum total protein ratio) for the development of SBP in cirrhotic patients with ascites and so are useful in early diagnosis. Total serum albumin and total ascetic albumin can be taken as diagnostic parameter for SBP when compared to SCA.

Funding: Nil, Conflict of interest: None initiated, Permission from IRB: Yes

\section{References}

1. Hoefs JC, Hanna NC, Francisco L, Hopkins RR, Weines J, Montgomerie JZ. Spontaneous bacterial peritonitis. Hepatology 1982; 2(4): 399-407.

2. Ljubicic N, Bilic A, Babic Z, Roic D, Banic M. The Significance of low levels of total proteins, albumins, globulins and complement factors in ascetic fluid and the development of spontaneous bacterial peritonitis in patients with liver cirrhosis. Lijec Vjesn 1992; 114 (9-12):213-5.
3. Wilcox D, William E. Spontaneous bacterial peritonitis: A review of Pathogenesis, diagnosis and treatment. Medicine 1987; 66 (6): 447-56.

4. Henry RJ, Cannon DC, Winkelman JW. Clinical chemistry, principles and techniques, 2nd ed. Harper \& Row, Newyork.1974.

5. Doumas BT, Watson WA, Biggs HG. Albumin standards and the measurement of serum albumin with bromocresol green. Clin Chim Acta 1971; 31(1): $87-96$.

6. Albillos A, Cuervas MV, Millan I, Conton T, Mentes $\mathrm{J}$, Barrious C et al. Ascitic Fluid Polymorphonuclear cell count and serum to ascetic albumin gradient in the diagnosis of bacterial peritonitis. Gastroenterology. 1990; 98(1):134-40.

7. Pare P, Talbort J, Hoefs JC. Serum ascetic albumin gradient-A physiological approach to the different diagnosis of ascites. Gastroenterology. 1983; 85(2): 240-4.

8. Runyon BA, Hoefs JC. Ascitic fluid analysis in the differenciation of spontaneous bacterial peritonitis from gastrointestinal tract perforation into ascetic fluid. Hepatology 1984; 4(3):447-80.

\section{How to cite this article?}

R.K, Bhushan M, Nigam P.Spontaneous bacterial peritonitis: risk factors and relationship to serum-ascites albumin gradient in chronic liver disease patient. Int J Med Res Rev 2016;4(9):1702-1705.doi:10.17511/ijmrr. 2016.109.31. 